\title{
Heavy Metals Accumulations And Health Risk Assessment Of Faba Bean Grow On Soil Amended With Municipal Solid Waste Compost, Biochar And Co-Composted Biochar
}

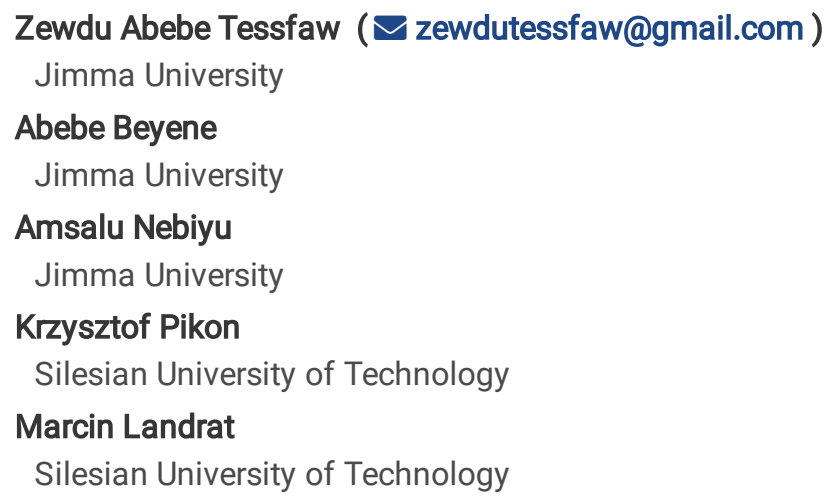




\section{Abstract}

Health risk assessment of heavy metals is crucial before large scale applications of municipal solid waste (MSW) as organic fertilizer. This study aimed to estimate $\mathrm{Pb}, \mathrm{Cd}$ and $\mathrm{Cr}$ accumulation and health risk in faba bean (Vicia faba $L$.) grow on soils amended with MSW compost, biochar and co-composted biochars (5\%, $15 \%$ and $25 \% \mathrm{w} / \mathrm{w})$. The heavy metal concentrations were measured by flame atomic absorption spectroscopy. Bioaccumulation Factor (BAF), Estimated Daily Intake (EDI), Hazard Quotient (HQ) and Hazard Index $(\mathrm{HI})$ were calculated. Results showed that $\mathrm{Pb}, \mathrm{Cd}$ and $\mathrm{Cr}$ concentrations in the amended soils and faba bean grain were lower than WHO permissible levels. The EDIs of $\mathrm{Pb}, \mathrm{Cd}$ and $\mathrm{Cr}$ in grains for all amendments were much lower than the reference doses established by USEPA and FAO/WHO. HQs and HIs of heavy metals were $<1$ for all amendments indicating that consumption of faba bean grow on MSW compost, khat biochar and co-composted biochar collected from Jimma city was safe related to human health risks. Low accumulation of heavy metals in faba bean indicating that the low fraction of e-waste in the MSW. Since faba bean grain is not accumulator, it's potential of heavy metals excluder needs further explorations.

\section{Introduction}

The management of municipal solid waste is becoming the major challenges in urban community in many developing countries (Karak et al., 2012; Menikpura et al., 2013). The solid waste collection rate is the lowest and even the collected solid waste is disposed to open landfills. The organic component of the urban waste is about 45-60\% the total solid waste generated in developing countries (Pattnaik \& Reddy, 2009). Improper management of biodegradable organic waste releases greenhouse gases such as carbondioxide and methane in the environment due to anaerobic digestion from open disposal sites which affects climate change. So, that a sustainable solid waste management scheme is required for the exponential increasing of municipal solid waste generations.

Municipal solid waste application to arable land is a sustainable practice of both soil fertility and waste management. Several studies have showed that MSW compost is common practice to improve the physical, chemical and biological properties of impoverished soils by supplying organic matter (Habib et al., 2015; Haghighi et al., 2016; Srivastava et al., 2016, 2018; Weerasinghe \& De, 2017). The organic part of municipal solid wastes is recognized as important source soil organic matter, which can provide essential soil nutrients (Ayilara et al., 2020; Lucchini et al., 2014).

However, a heavy metal contamination is the main challenge to use MSW for agricultural use. MSW could be contaminated by heavy metals from many sources such as house hold dust, electronics, plastics, paints and inks and pesticide (Chimuka \& Manungufala, 2009). All types of municipal solid waste (MSW) compost contain more heavy metals than the background concentrations present in soil and will increase their contents in amended soil and the heavy metal transfer into plants (Smith, 2009). Studies have showed that compost amended soils had increased significantly in the contents of $\mathrm{Cd}, \mathrm{Cr}, \mathrm{Cu}, \mathrm{Ni}, \mathrm{Pb}$ and $\mathrm{Zn}$ compared to untreated soils (Ayari, 2010; Carbonell et al., 2011). Consequently, there is evidence of phytotoxic effects, or accumulations of heavy metals in crop tissues that may pose a risk of human health from the applications of MSW compost to the soil (Basta et al., 2004; Paradelo et al., 2020; J. Singh \& Kalamdhad, 2011).

High levels of heavy metals in soil, water and food supply adversely affects food chain, human health and soil ecosystems. Therefore, consumption of heavy metal contaminated foods is the major route of human health risk (Guerra et al., 2012; Mahfooz et al., 2020). Heavy metals are non-biodegradable and persistent in the environment, which are known to cause toxic effects on animal and human health. Once they enter into our body, they are converted into more dangerous organic forms and accumulate in fatty organs such as liver, kidney and skin. Organic forms of heavy metals are water insoluble which is difficult to eliminate from our body and damage these organs. Thus, heavy metals especially, lead (Pb), cadmium (Cd), and Chromium ( $\mathrm{Cr}$ ) are the most toxic and affect human health even at low concentration (Khan et al., 2008; Qureshi et al., 2016; Shaheen et al., 2016; Volpe et al., 2009; Wassim et al., 2018). As heavy metals can play a role in the development of carcinogenic and non- carcinogenic diseases (Wassim et al., 2018a), a decreased in mental capacity, kidney damage, blood and bone disorders, and neurological damage are caused from exposure of heavy metals (Li et al., 2015).

Many research works were done to investigate the bioavailability and human health risk of heavy metals in soil amended with sewage sludge (Pascual et al., 2004; Singh \& Agrawal, 2008), soils and vegetables around waste incinerators (Li et al., 2015), and vegetables grow on soil irrigated with wastewater (Hossain et al., 2015; Mahfooz et al., 2020; Qureshi et al., 2016; Sharma et al., 2016; Woldetsadik et al., 2017). There were also research works on risk assessment of heavy metal on soil treated with organic waste compost (Chaney, 2018; Jiwan \& Kalamdhad, 2014; Soobhany et al., 2015). But, there is limited study focusing on risk assessments of heavy metals in 
plants grown on soil amended with municipal solid waste compost. Bioavailability of heavy metals in the edible portion of each crops varied significantly according to the type of crops (Chen et al., 2014; Edogbo et al., 2020). Leguminous vegetables were more likely to accumulate $\mathrm{Cr}$, while leaf vegetables tended to show higher levels of concentration of $\mathrm{Cd}$ and $\mathrm{Pb}$ (Chen et al., 2014). Before large scale agricultural applications of organic fertilizers derived from municipal solid waste, data on accumulation and health risk of heavy metals is very important. So, the applications of all organic wastes to arable land must be regulated with regard to tolerable amounts of nutrients and heavy metals (Seçer et al., 2016). Thus, the aim of this study was to assess the bioavailability and health risk of faba bean grow on soil amended with compost, khat biochar and co-composted biochars derived from municipal solid waste.

\section{Materials And Methods}

\subsection{Study Site and Sample Collection}

The field experiment was conducted at Debre Markos University agricultural college field laboratory site $\left(10^{\circ} 20^{\prime} \mathrm{N} 37^{\circ} 43^{\prime} \mathrm{E}\right)$ from February, 2019 to July, 2019 to investigate the effects of municipal solid waste compost, co-composted biochar and Khat biochar on the soil physicochemical properties and faba bean yield and physiology. Debre Markos University is located in Debre Markos town, North-westrn, Ethiopia. According to CSA (2010) estimation/forecast of the 2018, the town's population growth would have reached 111,313 (Mekuriaw and Gokcekus, 2019). To assess the health risk and bioavailability of $\mathrm{Pb}, \mathrm{Cd}$ and $\mathrm{Cr}$ on faba bean seeds grow on control compost, $5 \%, 15 \%, 25 \% \mathrm{w} / \mathrm{w}$ co-composted biochars, surface soil samples $(0-20 \mathrm{~cm})$ and faba bean seeds were sampled from all individual plots to make a bulk composite sample for each treatment

\subsection{Amendments}

A field experiment was conducted on a randomize complete block design with triplicate to study the effects of municipal solid waste compost, khat biochar and co-composted biochars on soil quality and faba bean grain yield. The treatments consisting of i) control compost ii), $5 \%$ co-composted biochar ( $5 \% \mathrm{w} / \mathrm{w}$ khat biochar $+95 \% \mathrm{w} / \mathrm{w}$ municipal solid waste mix), iii) $15 \%$ co-composted biochar ( $15 \%$ of khat biochar $+85 \%$ municipal solid waste mix), iv) $25 \%$ co-composted biochar ( $25 \%$ of khat biochar $+75 \%$ municipal solid waste mix) and v) khat biochar. Faba bean ranks first in its production volume and cultivated land among pulse crops cultivated in Ethiopia and it is valuable as the cheap source of protein in most Ethiopian diet.

\subsection{Sample collection}

Faba bean seeds (Vicia faba L.) with Dosha variety which is used as a test crop was identified and collected from Adet Agricultural Research Center (AARC).

The necessary field management practices were carried out as per the practices followed by the farming community around the study area. In addition, all the field experiments involving were conducted according the guideline written in Estefan et al., (2013) and the Faba bean growth Guideline in New England (Etemadi et al., 2015). Plant samples were collected according to the procedures described in (Jane M-F Johnson and Jack Morgan, 2010) for aboveground growth parameters analysis. The faba bean plants, about $10 \%$ (12 plants) were collected per plot. Sampling was done when the pods became brown to black in color.

\subsection{Analysis of soil and faba bean seed samples}

For determination of total heavy metal content of the amended soils and faba beans grain, $1 \mathrm{gm}$ oven dried soil /faba bean seed powder solution was digested by $5 \mathrm{ml} \mathrm{Di} \mathrm{acid}\left(\mathrm{HNO}_{3} \& \mathrm{HClO}_{4}\right)$ at $100^{\circ} \mathrm{C}$ for $2 \mathrm{hrs}$ (Upadhyay \& Sahu, 2012). Then after $3 \mathrm{ml}$ hydrogen peroxide was added to the remaining mixture and heated at $300^{\circ} \mathrm{C}$ for $2 \mathrm{hrs}$. After cooling the digested solution, it was filtered through Whatman filter paper 42 and diluted with distilled water on $100 \mathrm{ml}$ volumetric flask. $10 \mathrm{ml}$ soil and bean extracted solution of $\mathrm{Cd}$, Cr and $\mathrm{Pb}$ were determined by atomic absorption spectroscopy (with model NOVA 400P AAS) (Anderson, and Ingram, 1993; Jackson, 1958).

\subsection{Methods of health risk assessment heavy metals}

The risk of human health by intake of heavy metal contaminated crops is described by some concepts such as bio-accumulation factor (BAC), estimate daily intake (EDI), hazard quotient (HQ) and hazard index (HRI).

\subsubsection{Bioaccumulation factor (BAF)}


Bioaccumulation factor (BAF) is defined as the heavy metal accumulated in each plant tissue to that in soil solution and was calculated according to (Saleem et al., 2020) by equation, Eq. (1);
$\mathrm{BAF}=\mathrm{C}_{\text {plant }} / \mathrm{C}_{\text {soil }}$
eq (1)

Where, $C$ plant is heavy metal concentration in vegetable tissue $(\mathrm{mg} / 100 \mathrm{~g})$, and $C$ soil is metal concentration in soil $(\mathrm{mg} / 100 \mathrm{~g}$ dry soil).

\subsubsection{Estimated daily intake (EDI) of heavy metals}

Estimated daily intake (EDI) is defined as the maximum amount of a chemical that can be ingested daily over a lifetime with no appreciable health risk. It is expressed in terms of milligrams per kilogram of body weight. The EDI value of each metal of interest was determined by the equation used by (Khan et al., 2008) with slight modification as presented in Eq. (2).

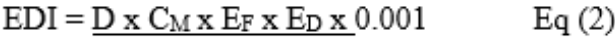 \\ $\mathrm{BW} \times \mathrm{AT}$}

where

$D$ is the daily faba bean consumption $\left(17.7 \mathrm{mg} \mathrm{day}^{-1}\right)$ per adult person;

$C_{M}$ is the mean concentration of metal in contaminated faba bean $\left(\mathrm{mg} \mathrm{kg}^{-1}\right.$ dry weight);

$E_{F}$ is exposure frequency (365 day/year);

$E_{D}$ is the exposure duration (66.7 years), average life time of Ethiopian from Human Development Report, 2019 (UNDP, 2019),

$B_{W}$ is reference body weight for an adult during survey assessment, which is $62.3 \mathrm{~kg}$;

AT is the average exposure time during a lifespan ( 66.7 yrs $\times 365$ days) and 0.001 is unit conversion factor. The overall data employed for the calculation of EDI is as compiled in Table 3.

The daily faba bean consumption (D) was obtained through a formal survey conducted in the study area. Interviewer of 383 persons in the range $50-75 \mathrm{~kg}$ body weight regarding their daily consumption rate of the faba bean tested was conducted. An average consumption rate of faba bean per person per day was calculated with an average body weight of $62.3 \mathrm{~kg}$. So, the daily intake of faba bean seed is $17.7 \mathrm{mg} /$ day. A common formula for calculating sample size in survey studies from a finite population (countable population) is given below according to Etikan and Babatope, (2019).

$$
\mathrm{n}=\frac{N * p * q * Z^{2}}{e^{2}(N-1)+Z^{2} * p * q}
$$

Where, $\mathrm{n}=$ Sample size; $\mathrm{p}=0.5$ (Proportion of population to be included in the sample i.e $50 \%$ ); $\mathrm{e}=0.05$, margin of error or acceptance error; $N=$ Population size $=111,313 ; Z=1.96$, for a confidence interval level of $95 \%, a$ is 0.05$) ; q=0.5$, none occurrence of events $=1-0.5$ $=0.5$.

\subsubsection{Hazard Quotient (HQ)}

A hazard quotient is the ratio of the potential exposure to a substance and the level at which no adverse effects are expected. An estimate of the non-carcinogenic potential hazard to human health $(\mathrm{HQ})$ is calculated as a fraction of determined dose to the reference dose. The health risks of the heavy metals were also determined by calculating their hazard quotients (HQ) according (Sharma et al., 2016) as shown in Eq. (3);
$\mathrm{HQ}=\frac{\mathrm{EDI}}{\mathrm{R}_{\mathrm{f}} \mathrm{D}}=$
Eq. (3)

Where, EDI is the mean vegetables intake per day $\left(\mathrm{mg} \mathrm{kg}^{-1}\right)$ and $R_{\mathrm{f}} D$ is the oral reference dose of the metal ( $\mathrm{mg} \mathrm{kg}^{-1}$ per day). $R_{\mathrm{f}} \mathrm{D}$ is an estimate of a daily oral exposure for the human population, which does not cause deleterious effects during a lifetime, generally 
used in EPA's noncancer health assessments. The $\mathrm{R}_{\mathrm{f}} \mathrm{D}$ values were set to be as follows ( $\mathrm{mg} \mathrm{kg}^{-1}$ bw-day): $\mathrm{Cd}\left(0.001 \mathrm{mg} \mathrm{kg}^{-1}\right.$ per day), $\mathrm{Cr}\left(1.5 \mathrm{mg} \mathrm{kg}^{-1}\right.$ per day) and $\mathrm{R}_{\mathrm{f}} \mathrm{D}$ for $\mathrm{Pb}\left(0.004 \mathrm{mg} \mathrm{kg}^{-1}\right.$ per day) was taken from WHO (1993) (Joint FAO/WHO, 1993).

\subsubsection{Hazard Index (HI)}

An exposure to more than one pollutant results in summation effects. Thus, hazard index (HI) is a vital index that assesses overall likely impacts that can be posed by exposure to more than one contaminant. When the $\mathrm{HI}$ is $<1$, this suggests that there will not pose health effects from consuming pollutants contained in a foodstuff (U.S. EPA, 1998). The HI is calculated as an arithmetic sum of the hazard quotients for each metal as shown in Eq. (3);

$$
H I=H Q P b+H Q C d+H Q C r=\frac{E D l, P b \times C m, P b}{R f D, P b}+\frac{E D I, C d \times C m, C d}{R f D C d}+\frac{E D I, C r \times C m, C r}{R f D C r} \quad \text { eq. (3) }
$$

Where $\mathrm{HQ}$ is hazard quotient of a heavy metal, EDI is estimated daily intake of a heavy metal, $C \mathrm{~m}$ is concentration of a heavy metal, and $R_{\mathrm{f}} D$ is a reference dose of a heavy metal.

Hazard quotient (HQ) assumes that there is a level of exposure known as the reference dose $\left(R_{f} D\right)$. It is estimated that a daily oral intake of the heavy metal at the reference dose will pose no reasonable risk even to sensitive populations, over a 70-year lifetime (Saleem et al., 2020).

\subsection{Statistical analysis}

Statistical significance of variation in content of heavy metals in soils and faba bean was determined by one-way analysis of variance (ANOVA) and Tukey's HDS test (at the 0.05 significance level) between treatments (Torrie and Steel, 1979). Statistical analysis was performed using the statistical package SPSS (IBM version 20).

\section{Result And Discussion}

\subsection{Heavy metal accumulation in soil}

The total concentrations of studied heavy metals in the top $20 \mathrm{~cm}$ of the soil layer were presented on Table 2 . The concentrations (mg $\left.\mathrm{kg}^{-1}\right)$ of heavy metals in the different amended soils were ranged as $\mathrm{Pb}(0.96 \pm 0.07-1.55 \pm 0.06), \mathrm{Cd}(0.40 \pm 0.06-1.09 \pm 0.03)$ and $\mathrm{Cr}$ $(1.50 \pm 0.13-2.86 \pm 0.07)$. The highest concentrations of heavy metals in the soil from the plot area amended with municipal solid waste compost, biochar and co-composted biochar was found for chromium $(\mathrm{Cr})$, followed by lead $(\mathrm{Pb})$ and cadmium $(\mathrm{Cd})$. Among the amended soils, the concentrations of $\mathrm{Pb}$ increased in the order of khat biochar $<25 \% \mathrm{w} / \mathrm{w}$ co- composted biochar $<$ compost alone $<$ $15 \%$ co-composted biochar $<5 \%$ co- composted biochar. The concentration of $\mathrm{Cd}$ in the amended soil increased in the order of khat biochar < compost alone < $15 \%$ co-composted biochar < 25\% co- composted biochar < $5 \%$ co-composted biochar. The Cr concentration among the amended soils also increased in the order of khat biochar $<$ compost alone $<25 \%$ co-composted biochar $<15 \%$ cocomposted biochar $<5 \%$ co-composted biochar.

Our results revealed that the concentrations of $\mathrm{Pb}, \mathrm{Cd}$ and $\mathrm{Cr}$ in the amended soils are much lower than WHO (1996) permissible levels, ( $\mathrm{Pb}$ (85), $\mathrm{Cd}(0.8)$ and $\mathrm{Cr}(100) \mathrm{mg} \mathrm{kg}^{-1}$ ), which is reported in Onyedikachi et al., (2018). Comparatively, the concentrations of heavy metals are lower in co-composted biochar than control compost and khat-derived biochars amended soils and faba beans. This is due to the organic amendments immobilized the heavy metals through formation of complex in the humic substances. Recently, considerable research has shown that biochar is effective in immobilizing heavy metals, thus reducing their bioavailility and mobility in compost piles. In support of this result, adding $5 \%$ biochar to the soils decreases the bioavailability and bioaccessibility of $\mathrm{Pb}$ by 75.8 and $12.5 \%$, respectively, compared to the unamended soil (Ahmad et al. 2012). 
Table 1

concentrations of $\mathrm{Pb}, \mathrm{Cd}$ and $\mathrm{Cr}$ observed in faba bean grain and soil amended with compost, co-composted biochars and biochar from MSW sources, values in the table are means \pm S.D.

\begin{tabular}{|c|c|c|c|c|c|c|}
\hline \multirow[t]{2}{*}{ Types of organic amendments } & \multicolumn{3}{|c|}{$\begin{array}{l}\text { Concentrations in soil } \\
\mathrm{mg} / \mathrm{kg}\end{array}$} & \multicolumn{3}{|c|}{$\begin{array}{l}\text { Concentrations in faba bean grain } \\
\mathrm{mg} / \mathrm{kg}\end{array}$} \\
\hline & $\mathrm{Pb}$ & Cd & $\mathrm{Cr}$ & $\mathrm{Pb}$ & Cd & $\mathrm{Cr}$ \\
\hline Compost alone & $1.14 \pm .10 \mathrm{a}$ & $.46 \pm .06 a$ & $2.17 \pm .23 a$ & $.37 \pm .04 a$ & $.04 \pm .01 a$ & $1.67 \pm .14 \mathrm{a}$ \\
\hline $5 \%$ co- composted biochar & $1.55 \pm .06 b$ & $1.09 \pm .03$ & $2.86 \pm .07 \mathrm{~b}$ & $.42 \pm .04 a$ & $.06 \pm .01 a$ & $1.83 \pm .08 b$ \\
\hline $15 \%$ co-composted biochar & $1.36 \pm .06 \mathrm{~b}$ & $.94 \pm .09 c$ & $2.79 \pm .15 b$ & $.54 \pm .04 \mathrm{c}$ & $.08 \pm .01 a$ & $1.84 \pm .02 \mathrm{a}$ \\
\hline $25 \%$ co-composted biochar & $1.22 \pm .04 a$ & $.99 \pm .06 c$ & $2.61 \pm .15 b$ & $.59 \pm .03 c$ & $.10 \pm .01 a$ & $2.02 \pm .14 d$ \\
\hline Khat-derived biochar & $.96 \pm .07 e$ & $.40 \pm .06 a$ & $1.50 \pm .13 e$ & $.37 \pm .04 a$ & $.04 \pm .01 a$ & $1.67 \pm .14 \mathrm{a}$ \\
\hline
\end{tabular}

Tukey HSD ( $p<0.05$; means within a column followed by different letters are significantly different).

\subsection{Heavy metal accumulations in faba bean grain}

The concentrations of $\mathrm{Pb}, \mathrm{Cd}$ and $\mathrm{Cr}$ in different faba bean seeds grow on municipal solid waste compost, biochar and co-composted biochar amended soils are presented on Table 1. The mean concentrations of different heavy metals for faba bean seeds were also in decreasing order of $\mathrm{Cr}>\mathrm{Pb}>\mathrm{Cd}$. Whereas the concentrations of $\mathrm{Pb}, \mathrm{Cd}$ and $\mathrm{Cr}$ in faba bean grain grow on different amendments decreased similarly in the order of khat biochar < compost alone $<5 \%$ co-composted biochar $<15 \%$ co- composted biochar $<25 \%$ cocomposted biochar.

In the present study, our results revealed that the accumulations of all heavy metals in faba bean grains significantly decreased in the MSW compost, biochar and co-composted biochars application. And the concentrations of these heavy metals are higher in soils than faba bean grown on the same soils. Literatures suggested that plants growing on toxic heavy metals contaminated soils cannot prevent metal uptake but, only restrict and hence accumulate in their tissues in varying degree. On their associations with soil toxic contaminants, plants can be classified as accumulator, excluders or indicators. This indicated that faba bean is not heavy metals accumulator plant.

The concentrations of $\mathrm{Pb}, \mathrm{Cd}$ and $\mathrm{Cr}$ in faba bean grains for all treatments were less than the JECFA (2011) permissible limits in plant which $\mathrm{Pb}(0.20), \mathrm{Cd}(0.1)$ and $\mathrm{Cr}(1.3) \mathrm{mg} \mathrm{kg}^{-1}$ (FAO/WHO, 2015; JECFA, 2016). The findings of this study is similar with the study by Nawaz et al., (2020) which the levels of $\mathrm{Cr}>\mathrm{Pb}>\mathrm{Cd}$ in vegetables grown on wastewater irrigated soil.

\subsection{Bioaccumulation factor (BAF)}

The bio-accumulation factors of $\mathrm{Cr}, \mathrm{Cd}$ and $\mathrm{Pb}$ in faba bean were lower than 1.0 for all the amendments (Table 2). A BAF value higher than one indicates that a plant is a hyper accumulator, whereas a value less than one is indicative of an excluder. Our finding indicated that faba beans grown on all the five amendments are lower or no accumulators of $\mathrm{Pb}, \mathrm{Cd}$ and $\mathrm{Cr}$. And there were no significant differences in the BAF of $\mathrm{Cr}$, $\mathrm{Cd}$ and $\mathrm{Pb}$ between faba beans grown on different soil amendments. The values obtained were in increasing order of $\mathrm{Cd}<\mathrm{Pb}<\mathrm{Cr}$ in faba bean grown on all amendments. The BAF values showed that relatively $\mathrm{Cr}$ was the highest uptake metal. According to research investigating the nature of metal binding mechanisms to compost show that composted residual derived from MSW has a high affinity for metal sorption due to complexation. Therefore, there is low heavy metal levels in soil solution and hence plant grains. 
Table 2

Effects of different organic soil amendments on bioconcentration factor (BCF) in faba bean seeds (Values are means of three replicates expressed on dry matter basis)

\begin{tabular}{|llll|}
\hline Types of soil amendments & \multicolumn{3}{l}{ Bio-accumulation factor } \\
\cline { 2 - 4 } & $\mathbf{P b}$ & $\mathbf{C d}$ & $\mathbf{C r}$ \\
\hline Compost alone & 0.33 & 0.08 & 0.76 \\
\hline 5\% co- composted biochar & 0.27 & 0.05 & 0.64 \\
\hline 15\% co- composted biochar & 0.39 & 0.08 & 0.66 \\
\hline 25\% co- composted biochar & 0.48 & 0.10 & 0.77 \\
\hline Khat biochar & 0.29 & 0.06 & 0.76 \\
\hline
\end{tabular}

\subsection{Estimated daily intake (EDI)}

The estimated daily intake of heavy metals in all the five treatments were increased in the order of $\mathrm{Cd}<\mathrm{Pb}<\mathrm{Cr}$ as presented on Table 3 . The EDIs for all heavy metals ( $\mathrm{Pb}, \mathrm{Cd}$ and $\mathrm{Cr}$ ) were highest in $25 \% \mathrm{w} / \mathrm{w}$ co-composted biochars, while lowest for khat biochar amended faba beans. According to US Environmental Protection Authority USEPA (USEPA, 1998) and Joint FAO/WHO Expert Committee on Food Additives (JECFA, 2003) cited in (Chen et al., 2014), the reference dose $\left(\mathrm{R}_{\mathrm{f}} \mathrm{D}\right)$ for $\mathrm{Cr}$, $\mathrm{Cd}$ and Pb were 1.5 and $1 \times 10^{-3} \mathrm{mg} \mathrm{kg}^{-1}$ and $3.6 \times$ $10^{-3}$ per day respectively. The highest mean estimated daily intake of $\mathrm{Pb}, \mathrm{Cd}$ and $\mathrm{Cr}$ was via dietary consumption of $25 \% \mathrm{co}-$ composted biochars amended faba beans, $0.017 \times 10^{-3}, 0.03 \times 10^{-3}$ and $0.57 \times 10^{-3} \mathrm{mg} \mathrm{kg}^{-1}$ of body weight per day, respectively, levels that were much lower than the reference doses. Thus, the consumption of faba bean growth on municipal solid waste compost, biochar and co-composted biochar collected from Jimma city was safe related to human health risks. Similarly, Guerra et al., (2012) observed that the daily ingestion of heavy metals was below the oral dose of reference, therefore, consumption of these vegetables can be considered safe and without risk to human health.

Table 3

Estimated daily intake (EDI) of $\mathrm{Pb}, \mathrm{Cd}$ and $\mathrm{Cr}$ values via consumption of faba bean grown on soil amended with compost, co-composted biochars and biochar from MSW sources (means \pm S.D)

\begin{tabular}{|llll|}
\hline Types of soil amendments & \multicolumn{3}{l|}{ EDI $(\mu \mathrm{g} / \mathrm{kg})$} \\
\cline { 2 - 4 } & $\mathrm{Pb}$ & $\mathbf{C d}$ & $\mathbf{C r}$ \\
\hline Compost alone & 0.10 & 0.01 & 0.50 \\
\hline 5\% co- composted biochar & 0.12 & 0.02 & 0.52 \\
\hline 15\% co- composted biochar & 0.15 & 0.02 & 0.52 \\
\hline 25\% co- composted biochar & 0.17 & 0.03 & 0.57 \\
\hline Khat biochar & 0.08 & 0.01 & 0.33 \\
\hline
\end{tabular}

\subsection{Hazard Quotient (HQ) and hazard Index (HI)}

Risk of intake of municipal solid waste compost, biochar and co-composted biochar was characterized by hazard quotient (HQ) and hazard index $(\mathrm{HI})$ as shown on Table 4. The hazard quotient for all amendments decreased in the order of $\mathrm{Pb}>\mathrm{Cd}>\mathrm{Cr}$. Among the amendments the $25 \% \mathrm{w} / \mathrm{w}$ co-composted biochar had the highest value of both hazard quotient and hazard index for all metals. The $\mathrm{HQs}$ and Hls values for all heavy metals determined in all treatments were less than one indicated that the studied population considered to be safe from consumption of faba bean grow on municipal solid waste compost, biochar and co-composted biochar. 
Table 4

The $\mathrm{HQ}$ and $\mathrm{HI}$ of $\mathrm{Pb}, \mathrm{Cd}$ and $\mathrm{Cr}$ values in faba bean amended with compost, co-composted biochars and biochar from MSW sources (means)

\begin{tabular}{|lllll|}
\hline \multirow{2}{*}{ Types of soil amendments } & $\mathrm{HQ}$ & \multicolumn{3}{r|}{$\mathrm{HI}=\sum \mathrm{HQ}=\mathrm{HQPb}+\mathrm{HQ} \mathrm{Cd}+\mathrm{HQ} \mathrm{Cr}$} \\
\cline { 2 - 4 } & $\mathrm{Pb}$ & $\mathrm{Cd}$ & $\mathrm{Cr}$ & \\
\hline Compost alone & 0.029 & 0.01 & 0.0003 & 0.04 \\
\hline 5\% co- composted biochar & 0.034 & 0.02 & 0.0004 & 0.05 \\
\hline 15\% co- composted biochar & 0.043 & 0.02 & 0.0004 & 0.06 \\
\hline 25\% co- composted biochar & 0.050 & 0.028 & 0.0006 & 0.08 \\
\hline Khat biochar & 0.023 & 0.007 & 0.0002 & 0.03 \\
\hline
\end{tabular}

\section{Recommendation}

Accumulation and health risk assessment of heavy metals is very important before recommendation to widely used MSW as organic fertilizer, since MSW could be contaminated with pollutants from industry sources. Data on the heavy metals levels in soil amended with organic fertilizer derived from MSW and crops grow on this soil is a tool for the well-being of population. During the application organic fertilizer derived from municipal solid waste, the risk of transference of heavy metals from soil to humans should be a matter of concern. In the present study, the accumulations of heavy metals in faba bean grow on soil amended with municipal solid waste compost, biochar and co-composted biochar collected from Jimma city waste disposal site was much lower than the WHO (1996) levels. Hence, the EDIs of $\mathrm{Pb}, \mathrm{Cd}$ and $\mathrm{Cr}$ were all far below the $\mathrm{R}_{\mathrm{f}} \mathrm{Ds}$, suggesting that the consumption of faba bean posed no health risk to the local population.

\section{Declarations}

\section{Author contribution statement}

Conceptualization, Z.A., K.P. and M.L.; methodology, Z.A., A.B. and A.N.; investigation, Z.A., A.B. and A.N.; resources, Z.A., A.B., A.N., K.P. and M.L.; data curation, Z.A., A.B., A.N., K.P and M.L.; writing-original draft preparation, Z.A., A.B. and A.N.; writing-review and editing, K.P. and M.L.; project administration, M.L.; funding acquisition, K.P. All authors have read and agreed to the published version of the manuscript.

\section{Funding statement}

This research did not receive any specific grant from funding agencies in the public, commercial, or not-for-profit sectors.

\section{Competing interest statement}

This manuscript was written and edited with the participations of all the authors. The authors declare no conflict of interest.

\section{Additional information}

No additional information is available for this paper.

\section{Acknowledgements}

The authors wish to thank Jimma University and Debremarkos University for their financial and logistic support. We also thank the staff of Debremarkos soil laboratory and Amhara Design and Supervision Work Enterprise Laboratory Services for providing support to conduct the laboratory determination.

\section{References}


1. Ahmad, R., Jilani, G., Arshad, M., Zahir, Z. A. \& Khalid, A. (2012). Bio-conversion of organic wastes for their recycling in agriculture: an overview of perspectives and prospects. 57(4),471-479.

2. Anderson, J. M. \& Ingram, J. S. L. Tropical Soil Biology and Fertility: A Handbook of Methods. The Journal of Ecology. 78 (2), 547 https://doi.org/10.2307/2261129 (1993).

3. Ayari, F. Heavy metal distribution in soil and plant in municipal solid waste compost amended plots. Int. J. Environ. Sci. Tech. 7 (3), 465-472 (2010).

4. Ayilara, M. S., Olanrewaju, O. S., Babalola, O. O. \& Odeyemi, O. Waste management through composting: Challenges and potentials. Sustainability (Switzerland). 12 (11), 1-23 https://doi.org/10.3390/su12114456 (2020).

5. Basta, N. T., Ryan, J. A. \& Chaney, R. L. (2004). Trace Element Chemistry in Residual-Treated Soil: OF TRACE ELEMENTS WITH COMMON Trace Element Reaction with Iron.Adsorption Journal Of The International Adsorption Society,49-63.

6. Carbonell, G. et al. Chemosphere Effects of municipal solid waste compost and mineral fertilizer amendments on soil properties and heavy metals distribution in maize plants (Zea mays L.). Chemosphere. 85 (10), 1614-1623

https://doi.org/10.1016/j.chemosphere.2011.08.025 (2011).

7. Chaney, R. L. (2018). Trace Elements in Municipal Solid Waste Compost. 9534. https://doi.org/10.1016/0961-9534(92)90028-0

8. Chen, Y., Wu, P., Shao, Y. \& Ying, Y. Health risk assessment of heavy metals in vegetables grown around battery production area. Scientia Agricola. 71 (2), 126-132 (2014).

9. Chimuka, L. \& Manungufala, T. E. Sources, Bioavailability and Fate of Heavy Metals and Organic Contaminants in Compost Manure. Dynamic Soil, Dynamic Plant. 1 (3), 32-38 (2009).

10. Edogbo, B., Okolocha, E., Maikai, B., Aluwong, T. \& Uchendu, C. Risk analysis of heavy metal contamination in soil, vegetables and fish around Challawa area in Kano State, Nigeria. Scientific African. 7, e00281 https://doi.org/10.1016/j.sciaf.2020.e00281 (2020).

11. Etemadi, F., Hashemi, M., Mangan, F. \& Weis, S. (2015). Fava beans Growers Guide in new England. https://ag.umass.edu/sites/ag.umass.edu/files/research-reports/fava_bean_guide_2.pdf.

12. Etikan, I. \& Babatope, O. A Basic Approach in Sampling Methodology and Sample Size Calculation. Med Life Clin. 1 (2), 1006 (2019).

13. FAO/WHO, 1995. (2015). General Standard for Contaminants and Toxins in Food and Feed (Codex Stan 193-1995). Jurnal Ekonomi Malaysia, 51(2), 39-54.

14. George Estefan; Rolf Sommer and John Ryan. Methods of Soil, Plant, and Water Analysis: A manual for the West Asia and North Africa Region: Third Edition. Beirut, Lebanon: International Center for Agricultural Research in the Dry Areas (ICARDA). 40 (7), 8389 https://doi.org/10.3969/j.issn.1000-565X.2012.07.015 (2013).

15. Guerra, F., Trevizam, A. R., Muraoka, T., Marcante, N. C. \& Canniatti-Brazaca, S. G. Heavy metals in vegetables and potential risk for human health. Scientia Agricola. 69 (1), 54-60 https://doi.org/10.1590/S0103-90162012000100008 (2012).

16. Habib, M., Khatun, R. \& Hossen, M. Impact of organic wastes on soil environment and yield of T-aman rice. Progressive Agriculture. 26 (2), 122-128 https://doi.org/10.3329/pa.v26i2.25966 (2015).

17. Hossain, M. S., Ahmed, F., Abdullah, A. T. M., Akbor, M. A. \& A. M Public Health Risk Assessment of Heavy Metal Uptake by Vegetables Grown at a Waste-water-Irrigated Site in Dhaka, Bangladesh. Journal of Health and Pollution. 5 (9), 78-85 (2015).

18. Jackson, M. (1958). Soil Chemical Analysis; (p. 498). Prentice Hall, Englewood Cliffs, New York. https://doi.org/org/10.1002/jpln.19590850311

19. Jane, M-F., Johnson \& Jack Morgan. Sampling Protocols. Chapter 2. Plant Sampling Guidelines. IN Sampling Protocols. R.F. Follett, Editor. 2, 1-10 (2010). www.ars.usda.gov/research/GRACEnet

20. JECFA. (2016). JOINT FAO/WHO FOOD STANDARDS PROGRAMME CODEX COMMITTEE ON CONTAMINANTS IN FOODS 10th Session WORKING DOCUMENT FOR INFORMATION AND USE IN DISCUSSIONS RELATED TO CONTAMINANTS AND TOXINS IN THE GSCTFF. april, 1-150. http://www.fao.org/fao-who-codexalimentarius/sh-proxy/en/?

21. Jiwan, S. \& S, K. A. (2014). Effects of Heavy Metals on Soil, Plants, Human Health and Aquatic Life. International Journal of Research in Chemistry and Environment, January 2011.

22. Joint, F. A. O. W. H. O. Expert Committee on Food Additives, World Health Organization \& Food and Agriculture Organization of the United Nations. (1993). Evaluation of certain food additives and contaminants: forty-first report of the Joint FAO/WHO Expert Committ. (n.d.). 
23. Karak, T., Bhagat, R. M. \& Bhattacharyya, P. Municipal solid waste generation, composition, and management: The world scenario. Critical Reviews in Environmental Science and Technology. 42 (15), 1509-1630 https://doi.org/10.1080/10643389.2011.569871 (2012).

24. Khan, S., Cao, Q., Zheng, Y. M., Huang, Y. Z. \& Zhu, Y. G. Health risks of heavy metals in contaminated soils and food crops irrigated with wastewater in Beijing, China. Environ. Pollut. 152 (3), 686-692 https://doi.org/10.1016/j.envpol.2007.06.056 (2008).

25. Li, N. et al. Science of the Total Environment Concentration and transportation of heavy metals in vegetables and risk assessment of human exposure to bioaccessible heavy metals in soil near a waste-incinerator site, South China. Science of the Total Environment, The. 521-522, 144-151 https://doi.org/10.1016/j.scitotenv.2015.03.081 (2015).

26. Lucchini, P., Quilliam, R. S., Deluca, T. H. \& Vamerali, T. Increased bioavailability of metals in two contrasting agricultural soils treated with waste wood-derived biochar and ash. Environ Sci Pollut Res Int. 21 (5), 3230-3240 https://doi.org/10.1007/s11356013-2272-y (2014).

27. Mahfooz, Y., Yasar, A., Guijian, L. \& Islam, Q. U. Critical risk analysis of metals toxicity in wastewater irrigated soil and crops: a study of a semi - arid developing region. Sci. Rep. 0123456789, 1-10 https://doi.org/10.1038/s41598-020-69815-0 (2020).

28. Maryam Haghighi, M. R. \& Barzegar, J. A. T. da S(2016). The effect of municipal solid waste compost, peat, perlite and vermicompost on tomato (Lycopersicum esculentum L.) growth and yield in a hydroponic system. International Journal of Recycling of Organic Waste in Agriculture, 5(3), 231-242. https://doi.org/10.1007/s40093-016-0133-7

29. Menikpura, S. N. M., Sang-Arun, J. \& Bengtsson, M. Integrated Solid Waste Management: An approach for enhancing climate cobenefits through resource recovery. Journal of Cleaner Production. 58 (October), 34-42 https://doi.org/10.1016/j.jclepro.2013.03.012 (2013).

30. Nawaz, A. et al. Health risk assessment of heavy metals due to untreated wastewater irrigated vegetables. Earth Sciences Pakistan (ESP). 4 (1), 25-33 https://doi.org/10.26480/esp.01.2020.25.33 (2020).

31. Onyedikachi, U. B., Belonwu, D. C. \& Wegwu, M. O. Human health risk assessment of heavy metals in soils and commonly consumed food crops from quarry sites located at Isiagwu, Ebonyi State. Ovidius University Annals of Chemistry. 29 (1), 8-24 https://doi.org/10.2478/auoc-2018-0002 (2018).

32. Paradelo, R., Villada, A. \& Barral, M. T. Heavy metal uptake of lettuce and ryegrass from urban waste composts. International Journal of Environmental Research and Public Health. 17 (8), 1-10 https://doi.org/10.3390/ijerph17082887 (2020).

33. Pascual, I., Antolín, M. C., García, C. \& Polo, A. (2004). Plant availability of heavy metals in a soil amended with a high dose of sewage sludge under drought conditions.291-299. https://doi.org/10.1007/s00374-004-0763-1

34. Pattnaik, S. \& Reddy, M. V. Bioconversion of Municipal (Organic) Solid Waste into Nutrient-rich Vermicompost by Earthworms (Eudrilus eugeniae, Eisenia fetida and Perionyx excavatus). Dynamic Soil, Dynamic Plant. 3 (2), 122-128 (2009).

35. Qureshi, A. S., Hussain, M. I., Ismail, S. \& Khan, Q. M. Evaluating heavy metal accumulation and potential health risks in vegetables irrigated with treated wastewater. Chemosphere. 163, 54-61 https://doi.org/10.1016/j.chemosphere.2016.07.073 (2016).

36. Saleem, M. H. et al. (2020). Morpho-physiological traits, biochemical response and phytoextraction potential of short-term copper stress on kenaf (Hibiscus cannabinus L.) seedlings. PeerJ, e8321, 1-20. https://doi.org/10.7717/peerj.8321

37. Seçer, M., Elmaci, Ã. L. \& Ceylan, Å. (2016). The Effects of Organic Wastes on Soil and Cotton Quality with respect to the Risk of Boron and Heavy Metal Pollution. International Journal of Agronomy, 2016(http://dx.doi.org/10.1155/2016/7438327). https://doi.org/10.1155/2016/7438327

38. Shaheen, N. et al. Presence of heavy metals in fruits and vegetables: Health risk implications in Bangladesh. Chemosphere. 152, 431-438 https://doi.org/10.1016/j.chemosphere.2016.02.060 (2016).

39. Sharma, A., Katnoria, J. K. \& Nagpal, A. K. (2016). Heavy metals in vegetables: screening health risks involved in cultivation along wastewater drain and irrigating with wastewater. SpringerPlus, 1-16. https://doi.org/10.1186/s40064-016-2129-1

40. Singh, J. \& Kalamdhad, A. S. Effects of Heavy Metals on Soil, Plants, Human Health and Aquatic Life. International Journal of Research in Chemistry and Environment. 1 (2), 15-21 (2011). https://www.researchgate.net/publication/265849316_Effects_of_Heavy_Metals_on_Soil_Plants_Human_Health_and_Aquatic_Life

41. Singh, R. P. \& Agrawal, M. Potential benefits and risks of land application of sewage sludge. Waste Manage. 28, 347-358 https://doi.org/10.1016/j.wasman.2006.12.010 (2008).

42. Smith, S. R. A critical review of the bioavailability and impacts of heavy metals in municipal solid waste composts compared to sewage sludge. Environ. Int. 35 (1), 142-156 https://doi.org/10.1016/j.envint.2008.06.009 (2009). 
43. Soobhany, N., Mohee, R. \& Kumar, V. Comparative assessment of heavy metals content during the composting and vermicomposting of Municipal Solid Waste employing Eudrilus eugeniae. Waste Manage. 39, 130-145 https://doi.org/10.1016/j.wasman.2015.02.003 (2015).

44. Srivastava, V. et al. Biochemical, physiological, and yield responses of lady 's finger (Abelmoschus esculentus L.) grown on varying ratios of municipal solid waste vermicompost. International Journal of Recycling of Organic Waste in Agriculture. 7 (3), 241-250 https://doi.org/10.1007/s40093-018-0210-1 (2018).

45. Srivastava, V., Sergio, A., Araujo, F., De \& Vaish, B. Biological response of using municipal solid waste compost in agriculture as fertilizer supplement. Reviews in Environmental Science and Biotechnology. 15 (4), 677-696 https://doi.org/10.1007/s11157-0169407-9 (2016).

46. Steel, G. D. T. J(1979). Process and procedures of statistics. A biometrical approach, 2nd edition. New York MCgraw Hill Book, 633. New York, USA

47. U.S. EPA (1998). Methods For Derivation Of Inhalation Reference Concentrations (RfCs) And Application Of Inhalation Dosimetry. U.S. Environmental Protection Agency, Office of Research and Development, Office of Health and Environmental Assessment, Washington, DC. (n.d.). 600/8-90/066F.

48. UNDP UNITED NATIONS DEVELOPMENT PROGRAMME: Human Development Reports. http://hdr.undp.org/sites/all/themes/hdr_theme/country-notes/ETH.pdf Retrieved on 28 August/2019. (2019). 2019.

49. Upadhyay, A. K. \& Sahu, R. (2012). Determination of Total Nitrogen in Soil and Plant. CAFT on Advances in Agro-Technologies for Improving Soil, Plant \& Atmosphere Systems, 18-19.

50. Volpe, M. G. et al. Heavy metal uptake in the enological food chain. Food Chem. 117 (3), 553-560 https://doi.org/10.1016/j.foodchem.2009.04.033 (2009).

51. Wassim, S., Mokrani, K. \& Tarchoun, N. Assessment of Lead, Copper and Cadmium Tolerance by Four Vegetable Species. American Scientific Research Journal for Engineering, Technology, and Sciences (ASRJETS). 47 (1), 76-87 (2018a).

52. Weerasinghe, T. K. \& De, S. I. H. W. K. Effect of applying different ratios of compost made of municipal solid waste on the growth of Zea mays L. (Corn). Journal of Soil Science and Environmental Management. 8 (3), 52-60 https://doi.org/10.5897/jssem2016.0609 (2017).

53. Woldetsadik, D., Drechsel, P., Keraita, B., Itanna, F. \& Gebrekidan, H. Heavy metal accumulation and health risk assessment in wastewater-irrigated urban vegetable farming sites of Addis Ababa, Ethiopia. International Journal of Food Contamination. 4 (1), https://doi.org/10.1186/s40550-017-0053-y (2017). 